\title{
Evaluation of Implementation of Disaster Management Policy of Local Disaster Management Board (BPBD) Karo
}

\author{
Tunggul Sihombing \\ Department of Public Administration \\ University of Sumatera Utara \\ Medan, Indonesia \\ tlumbantoruan@yahoo.co.id
}

\author{
Asima Yanty Sylvania Siahaan \\ Department of Public Administration \\ University of Sumatera Utara \\ Medan, Indonesia \\ asimayantysiahaan@gmail.com
}

\begin{abstract}
This research is based on factors that obstructed the effectiveness of the implementation of Sinabung disaster management policy in Karo regency. This research is based on Eugene Bardach theory based on criteria of legality evaluation, political acceptability and robustness under conditions of administrative implementation, and improvability and has not been fully effective used in overcoming the disaster of Mount Sinabung in Karo Regency.Using qualitative research method approach, this study reveals that evaluations conducted by the evaluator have not touched the legality side which discussed the overlapping of rules and the absence of Special Disaster Regional Regulations in the perspective of regional autonomy. The criteria of political acceptability reveal the disappearance of the role of the actors involved in accommodating the Sinabung disaster budget. Furthermore, based on the robustness criteria under the conditions of administrative implementation and improvability is the elaboration of the performance report without revealing whether the results and benefits of activities have been in accordance with the needs of refugees in the area where the eruption of Mount Sinabung eruption.
\end{abstract}

Keywords—policy evaluation, legality, political acceptability, robustness administrative implementation

\section{INTRODUCTION}

The eruption of Mount Sinabung is a problem faced in Indonesian soil territory. In fact, until now the problem has not been fully addressed as it focuses on providing physical buildings to reduce the impact of disasters. Institutionally, disaster management organization is contained in Presidential Decree no. 3 of 2001 on the National Coordinating Agency for Disaster Management and Refugee Management, followed up by Government Regulation no. 83 of 2005 on National Coordinating Agency for Disaster Management (BarkornasPB). To address the disaster, the government has issued Law no. 24 Year 2007 on Disaster Management, which aims to provide protection to the community at the same time considering various disaster risks in every development process. This law was born out of strategic issues arising from the weakness of previous disaster management rules. Substantially there is a paradigm shift in disaster management that previously focused on emergency response to disaster risk reduction. Then, the establishment of Regional Disaster Management Agency (BPBD) at the District / Municipal level is the authority of the local government. This is affirmed in Article 18 of Law no. 24 Year 2007 on Disaster Management. To carry out the obligation and perform its function as mediating structure (intermediary structure) which operationally translate macro policy to micro policy in accordance with the needs of the local government of Karo Regency to form Regional Disaster Management Agency of Karo Regency through Local Regulation no. 01 of 2014 on the Organization and Working Procedures of Karo District Technical Institutions and the Regulations of Karo Regent (No. 04 Year 2014 About Main Tasks, Functions and Job Descriptions Agency Regional Technical Institute of Karo Regency.

Of course, a policy can be said to succeed if the policy is the best alternative or solution in order to solve the problems faced by society (Keban: 2008; 86). In fact, the eruption of Mount Sinabung actually happened since August 27, 2010, then, on September 18, 2013 Sinabung volcano erupted again by releasing hot clouds and volcanic ash and thousands of residents of the surrounding settlements were forced to evacuate to safe areas (BPBD Karo; 2017).

At the end of January 2014 the condition of Mount Sinabung started to stabilize and planned refugees coming from outside the dangerous radius $(5 \mathrm{KM})$ can be discharged. However, February 1, 20014 found 14 people were killed and 3 people were injured by hot clouds glide when they came to Suka Meriah Village, Payung Subdistrict in danger zone. This illustrates that the reduction of the risk of Mount Sinabung disaster that has been done, seems to have not been successful. The Birth of Karo Regent's Regulation no. 04 Year 2014 Concerning the Main Duty, Function and Description of the technical institution for Disaster Mitigation in Karo District was late considering the occurrence of Mount Sinabung eruption in 2010 and its high intensity.

\section{CRITERIA In Public Policy Evaluation}

The problems that must be resolved by a policy, in terms of formulation, implementation and impact of a policy require evaluation studies, according to Rossi and Freeman (1993: 9). Evaluation is: "The systematic application of social research procedures for assessing the conceptualization, design, 
implementation, and utility of social intervention programs ". The definition explains that the actual evaluation activities are not simple, both in the procedure and the object of study which includes conception, design, implementation, to the benefits or impact of the program.

Rossi and Freeman (1993: 160) distinguish three types of programs that are substantially different in the procedures and objects of evaluation, ie new programs, established programs, and programs that are improvements of existing programs (incremental). Another approach in evaluating a program / policy is proposed by Dunn (2000: 611-622), which states that a number of different approaches will influence the indicators used, such as: approach based on the referred value system.

Some of the evaluation criteria presented by the experts concerned three things, namely: 1) program monitoring / process studies; 2) impact assessment studies; 3) economic efficiency or cost effectiveness studies (Jones, 1984: 210). Evaluation differs from monitoring which is a prerequisite for the evaluation.

To evaluate government policy, not all criteria serve as a benchmark for evaluation, as proposed by Bardach (2012: 41):

Not all criteria that come into play in an analysis are part of the evaluative plotline. Some are purely practical and are part of the analitic plotline. These criteria have to do with what happens to an alternative as it moves through the policy adoption and policy implementation process. The main ones are legaly, political acceptability, robustness under conditions of administrative implementation, and improveability.

As Bardach puts it, there is a completely intact section and there is a section that is an overall analysis. The use of this criterion is tailored to the actual conditions that occur as the process of policy adoption and policy implementation proceeds. The main one is legality, political acceptance, administrative support and ability to improve and improve (improvability) policy.

Differences determine the criteria lies in the value to be maximized, what things should be minimized because it has been satisfied or overall priority what needs to be reduced because it is better, but according to Bardach (2012: 41) criteria such as legaly, polictical acceptability, robustness under conditions of administrative implementation, and improvability are substantive. The legality of Bardach is that a proper policy should not violate the constitution, law, or general legal rights. Sometimes attempts to take speculative action on policies that may or may not be decided may be illegal when tested in court.

The legality criteria describes whether disaster management policies are legally constitutional, not contrary to existing laws or other policies. Because often a policy is changing and ambiguous (Bardach 2012: 41). In the event of any change or change of policy, it must be traceable whether the laws and regulations related to the existing Sinabung mountain disaster management in Karo Regency have an impact on the new policy..

Political Acceptance. Visible policies must be politically accepted, or at least not rejected. Unacceptable politics is a combination of two conditions; too much opposition (which may be wide or intense or both) and / or too little support (which may not be broad enough or less intense or both).

Political support from the relevant parties (actors) is the foundation for disaster management programs eruption of Mount Sinabung in Karo Regency can be sustainable. At least, if there is no political support, there is no rejection of the policy of the issue. That is, how political actors provide a supportive role in efforts to address the problem of the Sinabung mountain disaster, in addition to legal or legal aspects as well as in the political aspects as can be seen in the role of the House of Representatives in providing political support or in allocating budget as well as other assistance in the effort to solve the problem of Mount Sinabung disaster in Karo Regency. Thus, political acceptance visibly determines the effectiveness of implementation in the field in the disaster of Mount Sinabung in Karo Regency.

The cause of ineffectiveness of policy implementation, other than due to resources, that there are two sub variables that give a big influence on the effective implementation of policies related to robustness under the conditions of administrative implementation, improvability, namely bureaucracy, integrated with Standard Operating Procedures (SOP) and fragmentation or is the spreading of responsibilities of a policy on several organizational units (Edwards III 1980: 134).

\section{RESULTS AND DISCUSSION}

In line with the information gathered through a qualitative approach, related to the evaluation of the implementation of the eruption policy of Mount Sinabung eruption in Karo Regency, the researcher revealed that Robustness Under Conditions of Administrative Implementation, and Improveability is a substantive matter.

The improvement of disaster management can be achieved through participation in the implementation process of individuals or groups with experience in the field or those not involved in policy design. Referring to the view of Bardach (2012: 41) it can be seen from four things, namely (1) authority, (2) instutional commitment, (3) capability and (4) organization support.

\section{A. Authors and Affiliations}

Authority is intended as the right or opportunity of the Regional Disaster Management Agency of Karo Regency in making decisions related to its duties. The authority is very important because not all BPBD tasks are running effectively as planned.

The formation of BPBD Karo Regency is still relatively young so that in tackling the disaster especially eruption of Sinabung mountain still experience the constraint of division of authority and responsibility between BNPB and BPBD because many mechanisms have not been completed. This is understandable because the disaster prevention system eruption of Mount Sinabung nationally has not been in sync with the disaster management planning system in Karo District. However, the authority of BPBD Kabupaten Karo as a body having authority in accordance with Law no. 24 of 2007 on Disaster Management, followed by the Regional Regulation of 
Karo Regency no. 1 Year 2014 about the Organization Formation of Regional Disaster Management Agency of Karo Regency along with the Details of the Duties, Functions and Working Procedures of the Regional Disaster Management Agency of Karo Regency, BPBD who is responsible for managing the eruption of Mount Sinabung.

Disaster Management Implementation chapter stipulates that in conducting rehabilitation and reconstruction, the Regency / Municipal Government is obliged to use the regency/city allocated fund (APBD). In case the APBD fund is inadequate, these local governments may request assistance to the Provincial Government and / or the Central Government. This is the source of financial assistance for disaster management eruption of Mount Sinabung in Karo District.

Until now, the fund spent for eruption of eruption of Mount Sinabung in Karo District came from the Karo regency government through unexpected cost budgeting (BTT). Generally, the disbursement of BTT fund takes one to two months for disbursement. The need for Local Regulation on call fundis an urgent need to cope with the eruption of Mount Sinabung eruption in Karo District. The current condition of disaster management is quite responsive in terms of providing logistical support only, while its operational funding is still constrained by APBD disbursement.

Taking into account the above conditions that the authority of BPBD Karo District has been made an input for the government of Karo Regency in overcoming the problem of eruption of eruption of Mount Sinabung in its territory. According to Prestus (1978: 43) authority is considered to be a variant of power coffered by people and the institution by the will of the people. Authority is not inherent but granted on the basis of democratic decision making. Thus, the granting of authority is followed by the authority to take decisions in tackling the eruption problem of Mount Sinabung in Karo District.

\section{B. Institutional commitment}

Institutional commitment is a readiness to meet the needs of the duties of BPBD Karo Regency based on the policy that has been determined. This can be seen in the description of the position, functions and main tasks that are an important part of the organization. The ability to carry out what is his duty is addressed by how well implemented in accordance with what is planned. The principle that must be applied in every disaster management activity has been regulated in Law Number 24 Year 2007 on Disaster Management, which is as follows:

Fast and precise strategies in disaster management must be implemented quickly and accurately in accordance with the demands of the priority state. The reality in the field of speed and accuracy of response in tackling the victim has appeared. However, BPBD in obtaining aid funds for disaster management eruption Sinabung mountain has not been fully targeted according to the needs of victims of Mount Sinabung eruption.

Coordination and integration, apparently not yet fully realized, coordination between the executive, the legislative and the field actors (SAR) convoluted. There has been also the tendency of the budget diverted to the political sector, especially in the election of the Regional Head.

Use and benefit, is a principle that must be applied in any disaster management activities. Judging from the disaster management program so far has not included the educational benefit aspect, for example the training is mainly aimed at people who are in vulnerable areas of eruption of Sinabung mountain.

Transparency and accountability, is an important principle in disaster management is done openly and can be accounted for ethically and legally. The reality on the ground, the issue of aid funds has not been fully transparent. Among them, there are budgets that are not through BPBD recommendations and there are also budgets that are directly handed down by the central government, such as the budget aimed at the Siosar village relocation, Karo District Brand District originating from the unknown and unknown villages of Simacem, Bekerah and Suka Meriah recommendation of BPBD.

\section{USING THE TEMPlATE}

After the text edit has been completed, the paper is ready for the template. Duplicate the template file by using the Save As command, and use the naming convention prescribed by your conference for the name of your paper. In this newly created file, highlight all of the contents and import your prepared text file. You are now ready to style your paper; use the scroll down window on the left of the MS Word Formatting toolbar.

1) Partnership. Disaster issues are not only the responsibility of the government, therefore a partnership between the government, the public and other private parties is needed to solve the problem. In another sense, efforts to optimize cooperation between the government sector (state sector), the private sector (private sector) and the community sector (society sector). In essence, in the field that the partnership has been built, which includes the role of Karo district government with GBKP and Catholic or cooperation with non-governmental organizations.

2) Empowerment. Some activities and programs that realize community's self-reliant and self-confident resulting in a way out of the eruption of Mount Sinabung disaster.Various institutions and organizations in empowering disaster impacted communites such as the formation of the eruption village of Sinabung mountains in each sub-district, the Village Administration, in the cooperating villages, with communitymade organizations, such as TAGANA (Youth Disaster Preparedness Group) by the Social Service and BPBD.

3) Non-discriminatory. Non-discriminatory matteristhe absence of different treatment of gender, ethnicity, religion, race, and any political stream. Similarly, the reality on the ground, that it has reflected the absence of discriminatory and victim-oriented victim soul. This is evidenced by the role of awareness from the government, Muslim community (Youth Ansor) Nahdatul Ulama organization, Muhammadiah, from Christian like Indonesian Christian Church (GKI), Christian 
Indonesian Student Society (PMKRI), Protestant Batak Christian Church (GBKP) and Catholic church.

It is forbidden to spread religion or belief in times of emergency, especially through the provision of emergency aid and service. The reality in the field, there is no non-proletion in the eradication of the eruption of Mount Sinabung in Karo Regency.

Based on the findings in the field of the role of BPBD Karo District to carry out coordination and command functions in tackling the eruption of Sinabung eruption in its territory can not be implemented maximally especially in the pre disaster and post disaster stage. BPBD has been unable to implement coordination and command functions due to the lack of personnel, the role of SKPD in the field is not integrated with the BPBD command. Each has its own technical agenda in the field including SKPD does not have a special unit that handles the eruption of Mount Sinabung eruption.

This can be seen from some SKPD activities related to Sinabung eruption disaster management activities during emergency response simultaneously with BPBD activities in the field. Some SKPD have their own programs and responsibilities as well as the budget for eruption of eruption of Mount Sinabung. This is what prevents coordination with some related SKPD, because they (SKPD) have their own programs.

Two things that can be used as a basis for the implementation of good coordination are: first the structural foundation, the two basic human relations (Sughanda 1991: 29). In terms of the structural basis of clarity rather than the organizational structure underlying the establishment of BPBD Karo District. Robbins (2007: 101) argues that how work is

divided, grouped and coordinated formally through specialization elements of work, departmentalization, chain of command, span of control, centralization and decentralization as well as formalization. The foundation of human relations is related to the dedication, loyalty and commitment of each work unit functionally responsible for the eradication of the eruption of Mount Sinabung in Karo Regency.

The commitment in evaluating the implementation of the Sinabung eruption policy policy described above, Robbins (2007), Mowday (1982), Steers (1985) gives an outline, namely that organizational commitment is an attitude that reflects feelings of likes or dislikes personnel to the organization so as to survive as part of the organization. The commitment form is not only passive loyalty but involves an active relationship in an effort to give every effort for the success of the organization concerned. In addition, Mustopadidjadja (2000) understands the importance of commitment to the benefits and the importance of joint responsibility in the achievement of goals. Thus, in eradicating the eruption of Mount Sinabung, it is not enough if it is only institutional commitment, but it must be able to implement the commitment of all the heart in the field, not half-hearted commitment.

The personnel of BPBD are individuals who are ready to work without time even though the holiday, although later still possible to change the situation, which happened out and entered as a member of BPBD of SKPD in Karo Regency.
Commitment leaders BPBD Karo Regency according to the researchers is quite high because at a critical time, such as eruption of Mount Sinabung eruption at the stage of emergency response is required to make the right decision and responsive. This is evidenced by the response from the leadership of BPBD in the eradication of eruption of Mount Sinabung based on humanitarian considerations and the prevention of social conflict is the main thing.

\section{B. Capability}

Ability possessed by staff of BPBD Karo Regency in facing the uncertainty and environmental change that happened in context of eruption of eruption of Sinabung mountain, that is the ability of organination to solve the problem, perception to change of existing policy through the mobilization of existing resources to influence the purpose which have been determined through selected strategies. Katz (in stoner 1990) explains that the manjerial ability is viewed from the aspect; conceptual skill, human skill and tecnical skill.

\section{Conceptual skills}

Conceptual skill involves the formulation of ideas. Managers understand relationships abstract relationships, develop ideas, and solve problems creatively. The emphasis of this aspect is problem solving through a collaborative process with the formulation of conceptual ideas of BPBD Karo District has a contingency plan document designed to reduce the risk caused by the eruption of Mount Sinabung. This activity is a form of cooperation between the government, community and non-governmental organizations as an effort to improve the preparedness of the eruption of Mount Sinabung eruption. In the contingency plan, simulations are developed, such as Hazard Rating, Event Determination, Threat Scenarios, and Affected Areas. Associated with conceptual skills in disaster management eruption of Mount Sinabung, one of the capabilities owned by BPBD Karo Regency is the ability of cooperation and problem solving through the incorporation of ideas is a step that has been taken.

\section{Human Skill}

According to Katz that "human skills are equally important at all levels of management, because all managers must deal directly with people". This is seen through the dissemination of contingency plans that have been prepared to the community by BPBD Karo District in the face of the eruption of Mount Sinabung disaster in the region. This activity takes place when a disaster does not occur between the government, the community, NGOs or international agencies.

At the time of the disaster occurred BPBD Karo District mobilize all power Infrastructure Facilities personnel, military / police, Related Agency / Agency, BASARNAS, Universities, PMI, and Volunteers from Karo District to provide assistance, relief and evacuation of disaster victims. Human skill in managing the logistics felt BPBD still many shortcomings, especially in responding to the special needs for victims of eruption of Sinabung eruption. 


\section{E. Technical skill}

According to Katz, technical skills tend to be more important for lower-level managers. This is because lowerlevel managers typically manage the organization's products and services. In view of Katz's opinion it is understood that technical ability is an essential ability that managers must have at the lowest level. It is understood that managers at this level usually manage employees by using tools that technically produce products and services.

Karo District BPBD has been seeking various training and simulation about Sinabung eruption disaster management. Some related SKPD have been prepared from start to train existing staff at health center like health center and hospital. Technically also the training of preparedness to face the threat of eruption of Mount Sinabung has been followed by many staffs in SKPD involved in eruption disaster eruption Sinabung. This is done to improve the ability of human resources are still minimal in terms of knowledge disaster eruption Sinabung mountain. Related to the field data about the lack of available resources that have knowledge about disaster in Karo Regency is known that some training both nationally and internationally has been done by some people in the logistics and disaster department of BPBD Karo Regency. The gap encountered in the field, namely that the views of international NGOs, namely that the Karo District Government has never conducted a risk analysis of the eruption activities of Mount Sinabung, either from the consequences of organizational management related to risk management, as well as human actions and natural factors. It is known that the activities of managing risk management can be done in the mitigation phase when disaster does not occur, and indeed the consequences require a lot of funds for this activity in addition to managing risk.

4) Organizational Support. Organizational Support is how the organization in this case the Regional Disaster Management Agency of Karo Regency can support the eruption of eruption of Mount Sinabung in its territory. In contrast to Organizational support that uses the perception of employees on the organization, how to make employees prosperous, make employees comfortable and level of awareness of the organization to its employees through the role of leaders for example according to the researchers.

Based on the facts in the field, that structural disaster mitigation efforts have been carried out, as the implementation of relocation activities for the victims of the eruption of Mount Sinabung in Siosar Village, Brand Sub-district, Karo Regency through regulation steps on building, structural modification and residential construction, this relocation activity is very difficult to do because it relates to community behavior.

Non-structural mitigation, among others, by issuing regulations related to eruption of eruption of Mount Sinabung and improvements of policy, guidance implementation implementation guidance and technical guidance related to anticipation of eruption of Sinabung mountain disasters. In terms of education, the community is given an understanding by way of socialization and counseling, training to anticipate how to control behavior in the face of the eruption of Mount Sinabung. Some activities undertakensuch as the preparation of contingency plans designed by BPBD Karo District involving several related agencies. Non-structural mitigation activities are known to still not get the main priority in Karo District because each of the several related agencies have routine activities that must be run.

Thus, the evaluation of the implementation of disaster management policy eruption of Mount Sinabung in Karo Regency based on criteria Robustness under conditions of administrative implementation, and improvability has not been fully able to provide results and benefits in accordance with the needs of communities in the areas of refugee disaster eruption of Sinabung and evaluation more to monitoring activities followed up with work performance report. According to the researcher, this has an impact on the eruption of Sinabung eruption in Karo Regency in terms of service quality. In terms of programs and activities that have been done several efforts made to strive to meet the standards and procedures remain in running disaster eruption Sinabung eruption in routine.

From the activities that have been done by BPBD Karo Regency as evaluator has not pay attention to strong efforts in achieving the result of Robustness unfer conditions of administrative implementation, and improvability criteria. This is evident from the concept of evaluation assessment that has not yet compared the achievement of the eruption target of Mount Sinabung eruption from the organizational support such as human resources, budget, facilities and infrastructure and disaster services. Findings revealed that one of the factors that cause the effectiveness of the evaluation of the implementation of disaster management policy eruption of Mount Sinabung in Karo Regency based on the criteria in question is the capability of the organization itself.

\section{CONCLUSION}

In line with the results of research indicating that the evaluation of the implementation of disaster management policy eruption of Mount Sinabung in Karo District conducted by the evaluators did not go well. It is said that because the robustness criteria unfer conditions of administrative implementation, and improvability have not been used as a basis for evaluating policy implementation.

In general, the results of the study indicate that the evaluation of the implementation of disaster management policy eruption of Mount Sinabung erupted by the Regional Disaster Management Agency (BPBD) Karo District more emphasis on how the technical implementation of the rescue, distribution of aid to victims of Sinabung eruption. The role of the evaluator is limited to performing the monitoring and reporting functions of the financial accountants as well as the administrative activities of the offices. This fact indicates that evaluations conducted by evaluators have not yet touched the robustness criteria under the conditions of administrative implementation and improvability because the evaluation by BPBD Karo is only a translation of the performance report without revealing whether the results and benefits of activities have been in accordance with the needs of the displaced people of the Sinabung eruption which until now was in the area of evacuation places. Efforts to improve the policy to make alternative solutions have not yet reached the mechanism to 
create a recommendation for effective eradication of the eruption of Mount Sinabung eruption.

Thus, through the results of research that researchers have done then the new concept proposed in this research, namely the successful evaluation of the implementation of disaster management policy eruption of Mount Sinabung must be supported by the role of society, competent institutions, and profesional organizational evaluation capabilities.

\section{SUGGESTION}

1) In the evaluation of the implementation of disaster management policy eruption of Mount Sinabung is indispensable an organization consisting of various professional evaluators both coming from universities and independent agencies that are specifically assigned and authorized officially to improve policy performance.

2) Policy evaluation should be consistently used as the basis for decision-making by regional heads and technical implementers to improve the disaster management policy of eruption of Mount Sinabung.

\section{REFERENCES}

[1] Bardch, Eugene, 2012, A Practical Guide for Policy Analysis: The Eiightfold Path to More Effective Problem Solving. Fourth edition. California : Sage Publications

[2] Creswell, John. M, 2010. Research Design ; Pendekatan Kualitatif, Kuantitatif, dan Mixed.

[3] Yogyakarta : Pustaka Pelajar.
[4] Dunn, William N. 2000. Pengantar Analisis Kebijakan Publik Edisi ke2. 1986. Administrasi Negara. Edisi Kelima. Jakarta: Erlangga.

[5] Garna Judistira K, 2001. Filsafat Ilmu. Bandung. Primaco Akademika Judistira Garna Foundating Bandung.

[6] Jones, O, Charles, 1984. An Introduction to the Study of Public Policy. California: Brooks/ Cole Publishing Company.

[7] Kusumasari, Bevaola. 2014 Manajemen Bencana dan Kapabilitas Pemerintah Lokal. Yogyakarta: Gava Media

[8] Maxwell, Joseph A., 1996. Qualitative Research Design: An Interactive Approach. London: SAGE Publications.

[9] Noorsyamsa, Syam. Djumara.2011. Evaluasi Kebijakan Diklat Kepemimpinan Tingkat II pada SPIMNAS Lembaga Administrasi Negara. Disertasi : Pasca Sarjana Universitas Padjadjaran.

[10] Puwanto, Erwan Agus.2012. Implementasi Kebijakan Publik : Konsep dan Aplikasinya di Indonesia. Yogyakarta : Gava Media.

[11] Rco, J. R. 2010, Metode Penelitian Kualitatif, Jenis, Karakteristik dan Keunggulannya, Jakarta : Grasindo.

[12] Rusli, Budiman. 2013. Kebijakan Publik : Membangun Pelayanan Publik yang Responsif. Bandung : Hakim Publishing.

[13] Rustandi. 2009 “Model Kebijakan Pengembangan Wilayah Pesisir yang Berkelanjutan dan Berperspektif Mitigasi Bencana Alam di Pesisir Indramayu dan Ciamis. Disertasi : Sekolah Pasca Sarjana IPB.

[14] Vedung, E. 2005. Public Policy and Program Evaluation. 3rdedition. New Brunswick, USA ; Transaction Publishers

[15] Wibawa, Samodra, dkk, 1993, Evaluasi Kebijakan Publik, Jakarta: PT Raja Grafindo Persada

[16] Huiterma, D.,Rayner, T. Massey, E.,Haug, C. Hildingsson.2011 The Evaluation of Climate Policy: Theory and Emerging Practice in Europe. Diakses di http://www.Springer.com30/01/2012

[17] Supardiono Sobirin, R.W. Triweko, Chrisiana Yuni Kusmiati. 2007. Manajemen Bencana Gempa dan Tsunami : Suatu masukan untuk pasca bencana di Nanggroe Aceh Darussalam dan Sumatera Utara. 